\title{
SARANA OLAHRAGA HIBURAN KEMANG
}

\author{
Stevanny Janto ${ }^{1)}$, Timmy Setiawan ${ }^{2)}$ \\ ${ }^{1)}$ Program Studi S1 Arsitektur, Fakultas Teknik, Universitas Tarumanagara, stevannyj@yahoo.com \\ 2) Program Studi S1 Arsitektur, Fakultas Teknik, Universitas Tarumanagara, timmy@unitricipta.com
}

\begin{abstract}
Abstrak
Pariwisata di Indonesia memiliki potensi besar untuk mendukung roda perekonomian Negara. Salah satu wisata yang sedang dikembangkan adalah Wisata Olahraga yang merupakan penggabungan antara kegiatan olahraga dan wisata. Melalui penyelenggaraan acara wisata olahraga ini, Indonesia dapat mempromosikan area wisata di berbagai daerah. Berdasarkan data dari BPS (Badan Pusat Statistik) pada 2015, kurang dari satu per tiga penduduk Indonesia rutin berolahraga, sehingga angka partisipasi olahraga di Indonesia masih sangat rendah. Jakarta merupakan kota metropolis dan Ibukota Indonesia yang memiliki akses dan trasnportasi yang lebih lengkap dan mudah dijangkau dibandingkan daerah lainnya. Jakarta Selatan yang merupakan kota administrasi paling kaya dibandingkan wilayah lainnya dengan kondisi lingkungan yang hijau, tenang dan teduh yang merupakan karakteristik penting untuk destinasi wisata olahraga. Pada 2016, BPS menganalisis keberhasilan pembangunan manusia melalui indikator Indeks Pembangunan Manusia (IPM) dan Jakarta Selatan merupakan yang tertinggi, tetapi berdasarkan data Riskesdas pada 2013, 42.1\% warga Jakarta Selatan mengalami obesitas, sehingga Jakarta Selatan dijadikan sebagai lokasi pengamatan yang berpotensi untuk dikembangkan sebagai lokasi architourism dengan tema olahraga. Mampang Prapatan menjadi daerah terpilih dikarenakan banyaknya usia produktif dan area yang tidak terlalu luas sehingga jangkauan olahraga menjadi lebih mudah. Proyek yang diusulkan berupa bangunan Sportainment yang bertujuan sebagai tempat untuk memenuhi kebutuhan olahraga, menjadi tempat hiburan untuk melepaskan penat, tempat untuk bersantai dan menghilangkan stress, dan ruang terbuka publik.
\end{abstract}

Kata kunci: Architourism, Pariwisata, Sportainment, Wisata Olahraga.

\begin{abstract}
Tourism in Indonesia has great potential to support the wheels of the country's economy. One of the tours being developed is Sports Tourism which is a combination of sports and tourism activities. Through the implementation of this sports tourism event, Indonesia can promote tourist areas in various regions. Based on data from BPS (Central Bureau of Statistics) in 2015, less than one-third of Indonesia's population routinely exercised, so the sport participation rate in Indonesia was still very low. Jakarta is a metropolis and capital city of Indonesia that has more complete and easy access and transportation than other regions. South Jakarta which is the richest administrative city compared to other regions with green, calm and calm environmental conditions which are important characteristics for sports tourism destinations. In 2016, BPS analyzed the success of human development through the Human Development Index (HDI) and South Jakarta indicators as the highest, but based on Riskesdas data in 2013, 42.1\% of South Jakarta residents were obese, so South Jakarta was used as a location for observation as a potential location of architourism with sports themes. Mampang Prapatan became the chosen area because of the large number of productive ages and not too large areas so that the reach of sports became easier. The proposed project in the form of Sportainment building which aims as a place to meet the needs of sports, becomes an entertainment place to release fatigue, a place to relax and relieve stress, and public open space.
\end{abstract}

Keywords: Architourism, Sportainment, Sports Tourism, Tourism. 


\section{PENDAHULUAN}

Metropolis adalah istilah yang biasa digunakan untuk mewakili kota besar atau daerah perkotaan. daerah perkotaan kurang dari satu juta orang jarang dianggap metropolis dalam konteks kontemporer. Kota besar memiliki sejumlah kota yang lebih besar, tetapi yang bukan merupakan inti dari jumlah itu, umumnya tidak dianggap sebagai kota metropolitan tetapi bagian dari kota itu. Sebuah metropolis biasanya merupakan pusat ekonomi, politik dan budaya yang signifikan dari beberapa negara atau wilayah, dan sebuah tautan penting untuk konektivitas dan komunikasi regional atau internasional. Bentuk jamak dari kata itu adalah metropolis. Daerah Khusus Ibukota Jakarta (DKI Jakarta) adalah ibu kota negara dan kota terbesar di Indonesia. Jakarta merupakan satu-satunya kota di Indonesia yang memiliki status setingkat provinsi.

Jakarta adalah Metropolis karena Jakarta telah menjadi 'induk' bagi kota-kota disekitarnya. Salah satu karakter umum dari sebuah metropolis adalah signifikansinya dalam hal ekonomi, politik, serta keberagaman social dan budaya. Jakarta juga dianggap Metropolis karena kepadatan penduduknya yang tinggi, aktivitasnya yang padat, pergerakannya yang cepat, serta prinsip kapitalisme yang kuat. Dari data Mikro Data SUPAS 2015 terdata bahwa migrasi penduduk terbanyak adalah di Jakarta dengan kepadatan aktifitas yaitu bekerja. Permintaan (demand) ekonomi yang semakin meningkat menyebabkan banyaknya penduduk bermigrasi ke kota Jakarta yang merupakan kota terpadat di Indonesia yang merupakan sentral utama perdagangan, perekonomian Indonesia untuk mengais rejeki.

Pekerjaan adalah sumber stress yang paling umum dalam kehidupan sehari-hari, diikuti oleh uang, masalah keuangan, dan masalah keluarga. Seiring gaya hidup yang semakin sibuk, pekerjaan akan menghabiskan lebih banyak hidup untuk kesibukan tersebut dan merasakan waktu yang kurang. Padatnya pekerjaan yang menimbulkan stress juga menyebabkan masyarakat Jakarta membutuhkan hiburan untuk menghilangkan penat, juga efek dari pekerjaan yang menguras waktu menyebabkan kurangnya waktu berolahraga. Hasil Riset Kesehatan Dasar (Riskesdas) pada 2013, juga menunjukkan perimbangan jumlah penduduk DKI Jakarta yang mengalami kondisi obesitas lebih tinggi dibandingkan angka nasional. Bahkan pada kelompok anak-anak, persentase penduduk obesitas di lbu Kota bahkan mencapai dua kali lipat proporsi Indonesia. Menurut keterangan dari Kementerian Kesehatan, pola hidup merupakan sebab utama bagi warga Jakarta. Kelebihan konsumsi karbohidrat, lemak, juga makan kurang serat dan kurang olahraga sepertinya merupakan cermin dari tabiat hidup warga ibu kota.

Angka partisipasi olahraga di Indonesia juga masih sangat rendah. Data Badan Pusat Statistik menunjukkan bahwa pada 2015, jumlah yang rutin berolahraga belum mencapai sepertiga dari total penduduk, hanya 27,61 persen penduduk Indonesia yang melakukan olahraga minimal sekali dalam seminggu. Dari data yang ada menggambarkan bahwa kurangnya olahraga merupakan salah satu permasalahan warga ibukota. Dimana bila ditelaah pada beberapa daerah di Jakarta, Jakarta Selatan memiliki sarana olahraga yang cukup banyak dibanding area lain namun kebanyakan sarana olahraga yang ada hanya untuk sejenis yoga dan pilates. Berdasarkan mapping juga daerah ini didominasi oleh pemukiman dimana membutuhkan sarana olahraga yang lebih menunjang.

\section{METODE}

Metode yang digunakan untuk mengumpulkan data yaitu riset perpustakaan dan sumber internet sebagai landasan untuk menyusun dasar teori yang berhubungan dengan permasalahan yang dibahas, pengamatan lapangan /survey langsung ke tempat yang dijadikan kawasan proyek, literatur yang terkait standar dan aturan data yang dapat dijadikan sebagai acuan dalam proyek, pengumpulan data dengan mempelajari kawasan titik terbangun dan studi teori dari buku - buku serta materi pembelajaran terkait. 
Pada proyek terbangun menggunakan teori Urban Design oleh Hamid Shirvani dalam bukunya "Urban Design Process" yang membahas elemen penting apakah yang membangun sebuah kota atau kawasan yang lebih modern namun terpadu. Berikut elemen tersebut:

- Tata Guna Lahan

- Bentuk dan Massa Bangunan

Bentuk dan masa bangunan tidak semata - mata ditentukan oleh ketinggian atau besarnya bangunan, penampilan maupun konfigurasi dari masa bangunannya, akan tetapi ditentukan juga oleh :

- Ketinggian Bangunan

- Kepejalan Bangunan

- Koefisien Lantai Bangunan (KLB)

- Koefisien Dasar Bangunan (Building Coverage)

- Garis Sempadan Bangunan (GSB)

- Langgam Langgam atau gaya dapat diartikan sebagai suatu kumpulan karakteristik bangunan dimana struktur, kesatuan dan ekspresi digabungkan di dalam satu periode atau wilayah tertentu. Peran dari langgam ini dalam skala urban jika direncanakan dengan baik dapat menjadi guide line yang dapat menyatukan fragmen-fragmen dan bentuk bangunan di kota.

- Skala

- Material

- Tekstur Dalam sebuah komposisi yang lebih besar (skala urban) sesuatu yang dilihat dari jarak tertentu maka elemen yang lebih besar dapat menimbulkan efek-efek tekstur.

- Warna

- Sirkulasi \& Parkir

- Ruang Terbuka

- Area Pedestrian

\section{DISKUSI DAN HASIL}

Olahraga merupakan sarana menuju peningkatan kualitas dan ekspresi hidup yang lebih luhur bersama sesama manusia dan sebuah bentuk dari bermain yang lebih sempurna. Berolahraga memberikan efek relaksasi yang baik untuk semua orang dan membuatnya menjadi pribadi yang lebih bahagia. Pariwisata di Indonesia merupakan salah satu sektor yang memiliki potensi besar untuk mendukung roda perekonomian Negara. Salah satu wisata yang saat ini sedang dikembangkan adalah Wisata Olahraga (Sport Tourism) yang merupakan penggabungan antara kegiatan olahraga dan wisata dengan tujuan mengembangkan wisata olahraga yang menghibur dan menarik konsumen untuk memiliki liburan yang sportif, sehat, dan interaktif.

Architourism yang adalah arsitektur yang memiliki program wisata dengan unsur seni, sosial dan juga hiburan. Arsitektur dapat menjadi sebuah ruang masa depan dengan konsep yang kreatif dan inovatif sebagai atraksi wisata yang memperkenalkan keindahan sebuah kota dengan aktivitasnya yang beragam sehari-hari.

Adanya keinginan untuk mewadahi wisata olahraga di Jakarta, maka penulis mengajukan sebuah proyek berupa Sportainment yang merupakan sarana olahraga hiburan (perpaduan antara olahraga dan hiburan), dimana kegiatan utamanya adalah kegiatan olahraga yang dilakukan diwaktu senggang atau waktu luang dan tidak sekompetitif pertandingan olahraga pada umumnya. Program sportainment yang diusulkan memiliki unsur hiburan dalam bentuk olahraga sehingga tidak terlalu berat atau membosankan.

Berdasarkan data, wilayah Jakarta selatan dijadikan lokasi pengamatan karena memiliki Lingkungan yang hijau, tenang dan teduh merupakan karakteristik penting untuk destinasi 
wisata olahraga yang saat ini sedang ramai dibicarakan dan berpotensi untuk dikembangkan. Lokasi tapak berada di Mampang Prapatan karena banyaknya usia produktif di daerah ini dengan luas area yang tidak terlalu besar.

\section{Analisa Tapak}

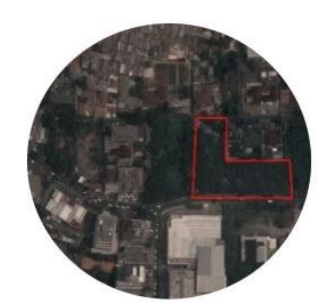

Gambar 1. Satelit Tapak

Sumber: Google Earth

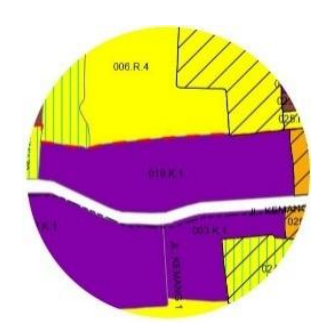

Gambar 2. Peruntukkan Tapak

Sumber: Dinas Tata Ruang Jakarta

\section{Fasilitas Sekitar Tapak}

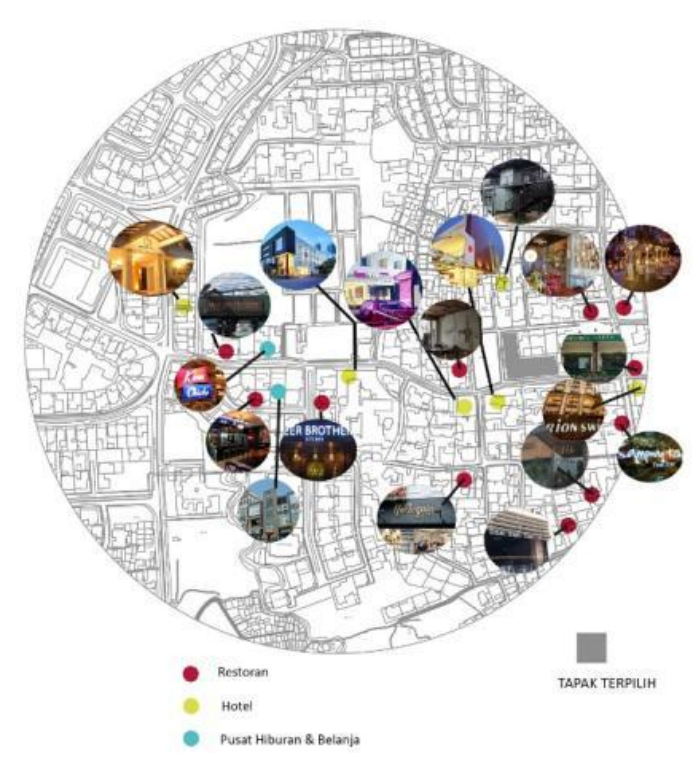

Gambar 3. Fasilitas Sekitar Tapak

Sumber: Dokumen Pribadi 
Terlihat pada pemetaan bahwa pada sekitar tapak merupakan daerah yang cukup padat dengan banyaknya hotel, restoran dan beberapa pusat belanja. Kawasan yang banyak menjadi tempat pemukiman ekspatriat menjadikannya kawasan yang ramai dan hidup.

\section{Analisa Jalan}

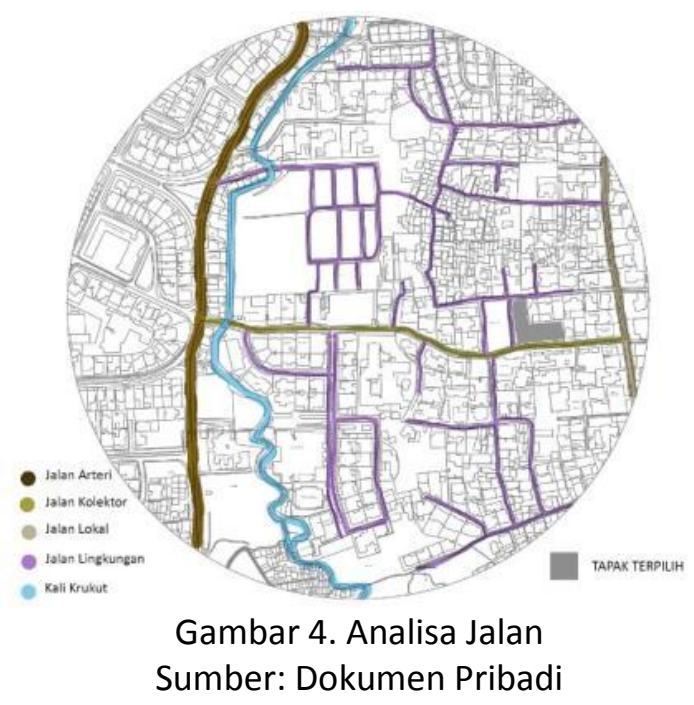

Tapak terlihat berada pada area depan jalan Lokal dimana cukup banyak kendaraan yang masuk cukup banyak. Tapak juga dikelilingi oleh jalan lingkungan yang menembus ke berbagai pemukiman sekitar. Terdapat juga kali yang melintasi area sekitar tapak.

\section{Aksesibilitas}

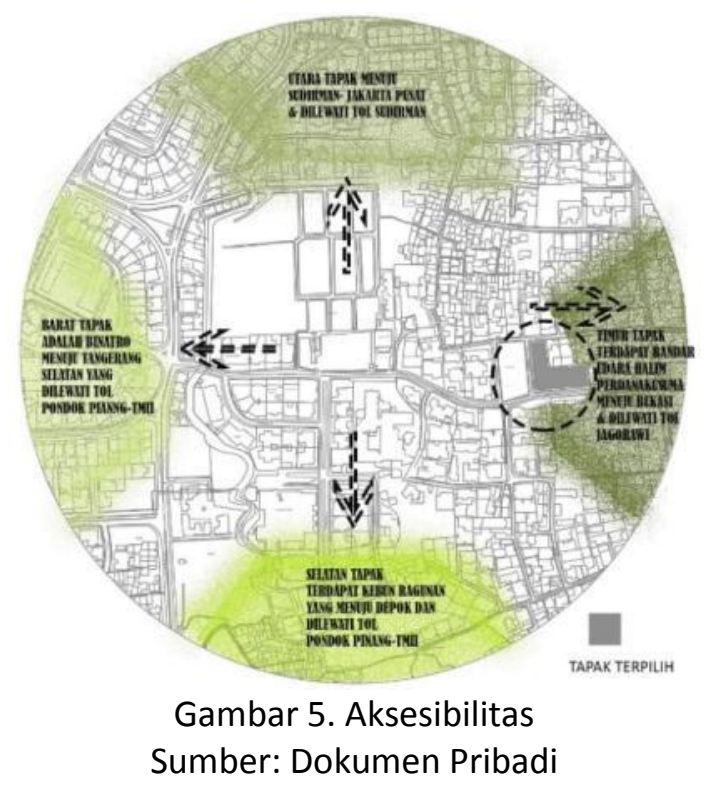

Jalan sekitar tapak atau kawasan Kemang ini menuju ke berbagai daerah. Dapat menuju Bekasi, Tangerang dan juga Depok. Akses yang cukup mudah menyebabkan kawasan ini juga kawasan modern yang cukup dikenal. 


\section{Cahaya Matahari}

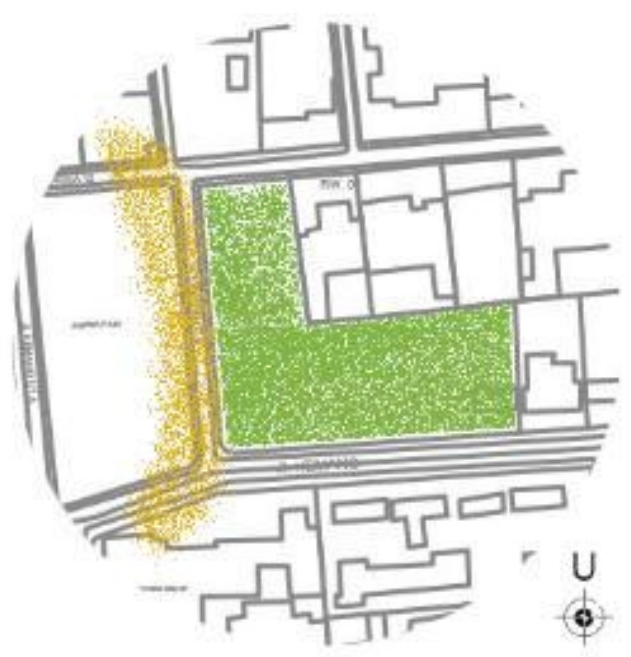

Gambar 6. Cahaya Matahari Sumber: Dokumen Pribadi

Tapak memiliki bagian kiri atau samping yang terkena cahaya matahari, dimana bagian itu adalah menghadap bagian barat tapak.

\section{Kebisingan}

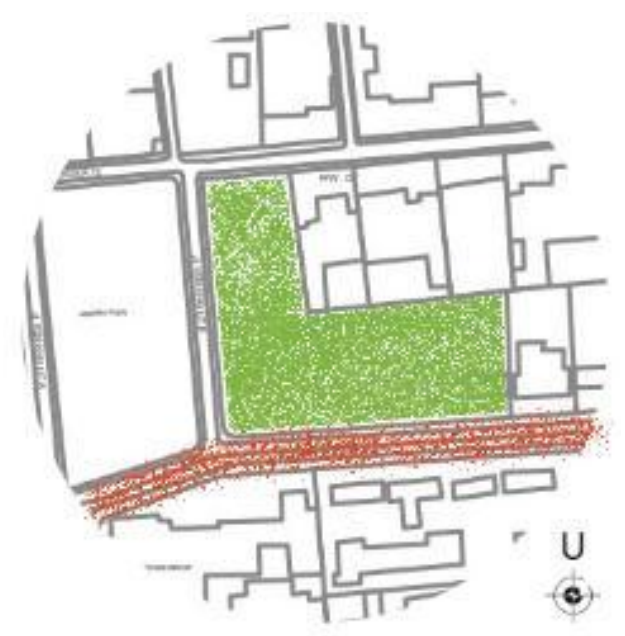

Gambar 7. Kebisingan

Sumber: Dokumen Pribadi

Jalan didepan tapak adalah jalan kolektor yang cukup banyak dilalui kendaraan, sumber kebisingan terbanyak bersumber dari jalan kolektor tersebut.

\section{Sekitar Tapak}

Tapak dikelilingi oleh jalan dan juga pertokoan disebelah timur tapak, jalan sekitar tapak merupakan jalan kolektor dan jalan lingkungan. 


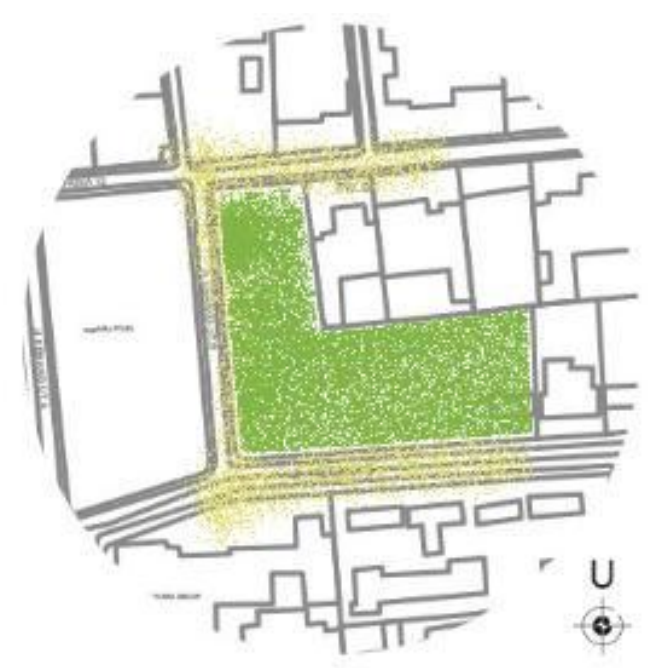

Gambar 8. Sekitar Tapak

Sumber: Dokumen Pribadi

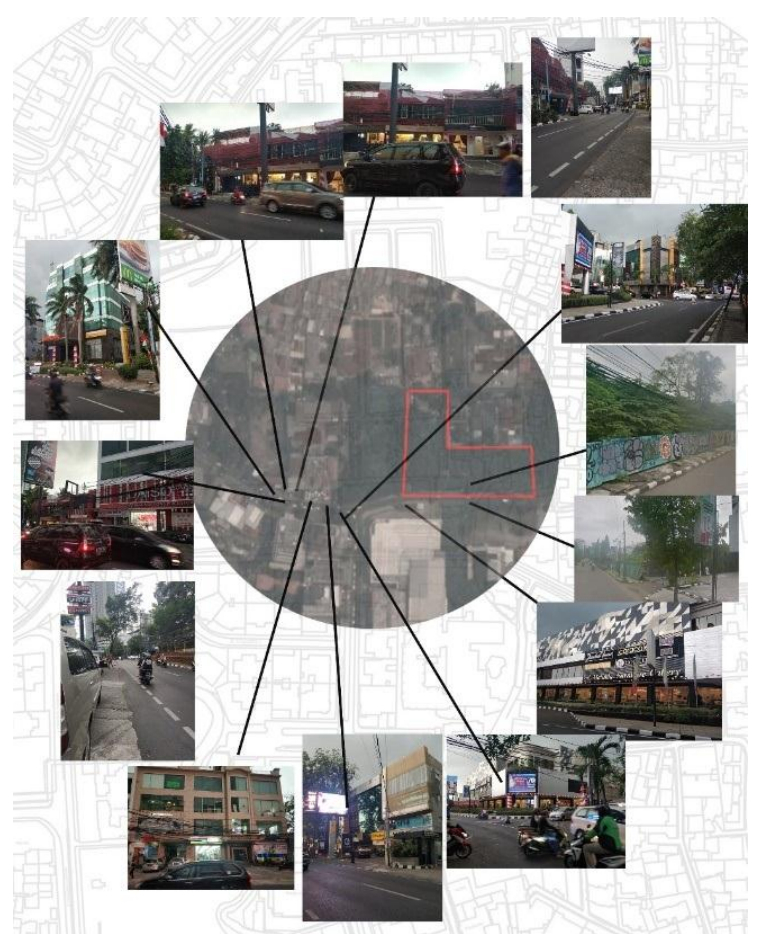

Gambar 9. Foto Hasil Survei

Sumber: Dokumen Pribadi

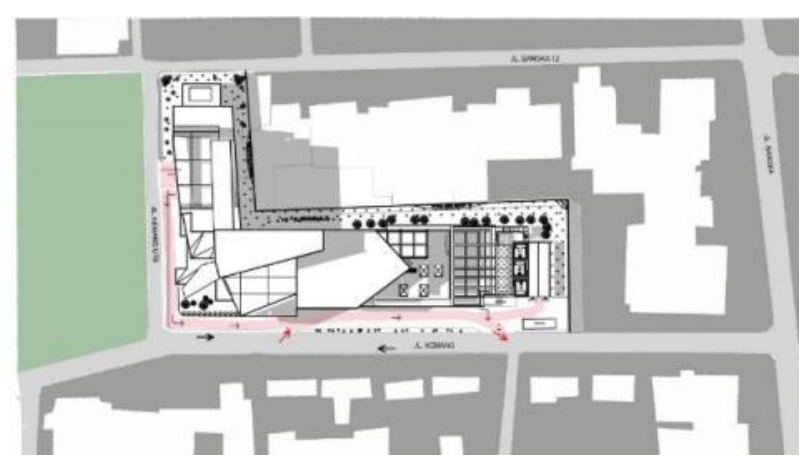

Gambar 10. Pencapaian Tapak

Sumber: Dokumen Pribadi 
Tapak berada di Jalan Kemang yang dapat dilalui melalui arah barat tapak yaitu dari Jalan Pangeran Antasari, dan arah timur tapak menuju ke Jalan Bangka. Untuk jalur kendaraan mobil dan motor berada pada Jalan Kemang yang merupakan jalan yang cukup sibuk dengan banyaknya bangunan komersial di sekitar tapak. Jalur servis dapat masuk melalui Jalan Kemang Utara B.

\section{Tujuan dan fokus perancangan:}

- Menyediakan fasilitas olahraga yang menunjang untuk segala kalangan, usia dan jenis kelamin.

- Menjadikan sarana olahraga sebagai sesuatu yang juga menghibur dan menghilangkan penat

- Sebagai pemenuh fungsi sosial (fungsi sosial ini dilakukan untuk kegiatan berkelompok serta rekreasi aktif).

- Untuk memperoleh kesegaran jasmani dengan olahraga yang menyenangkan.

- Menimbulkan kesempatan kerja dan memperkecil jumlah pengangguran.

- Merubah cara hidup masyarakat.

- Sebagai ruang terbuka publik

\section{Konsep Bentuk Bangunan}

Bangunan memiliki konsep dasar gubahan massa dengan jumlah lantai yang disesuaikan dengan aktifitas. Bentuknya disesuaikan dengan lingkungan sekitar dan program dalam tapak. Bangunan memiliki focal point yang merupakan bagian massa yang paling terlihat dan bentuknya menyesuaikan dengan kegiatan utama pada bangunan.

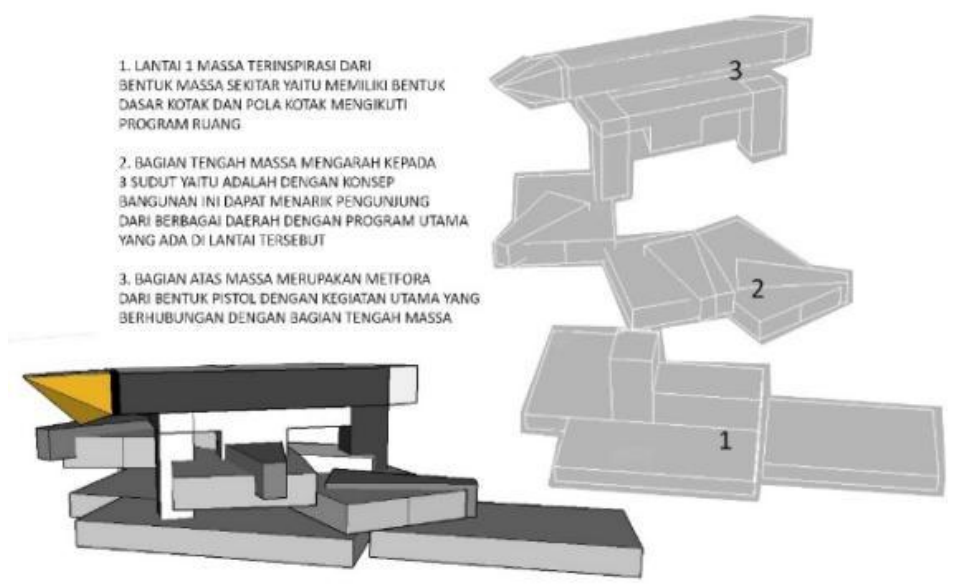

Gambar 11. Massa Awal

Sumber : Dokumen Pribadi

Massa diatas merupakan massa awal rancangan, namun dengan adanya perubahan program ruang tertentu, maka massa bangunan memilii sedikit perubahan pada bentuk terutama bagian tengah massa bangunan. 


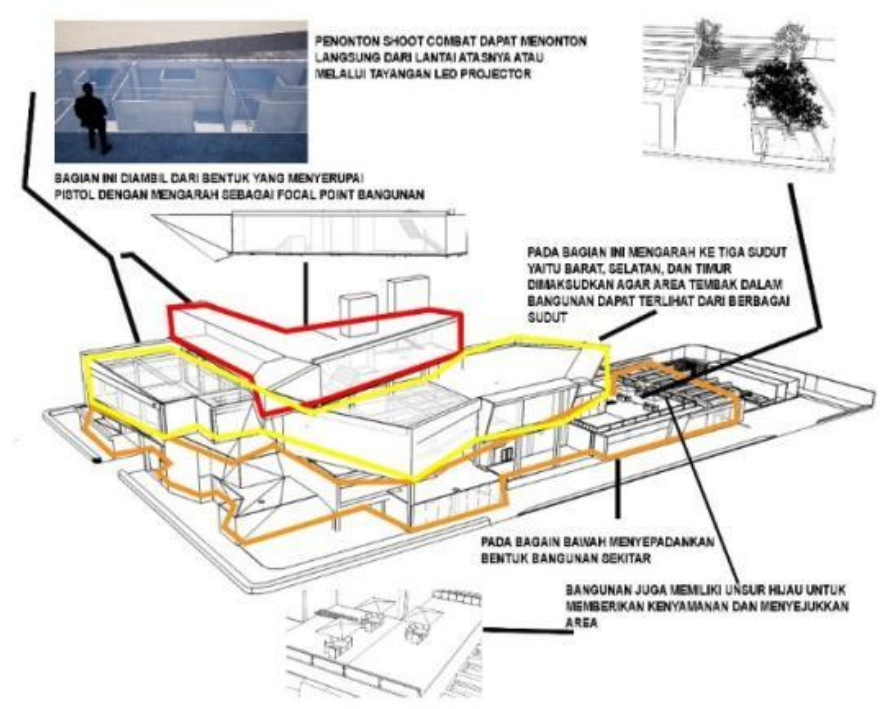

Gambar 12. Massa Terpakai

Sumber : Dokumen Pribadi

Massa awal dengan massa yang terpakai tidak mengalami banyak perubahan, hanya bentuk bagian tengah massa dan bagian atas massa yang berubah dikarenakan mengikuti fungsi program ruang.

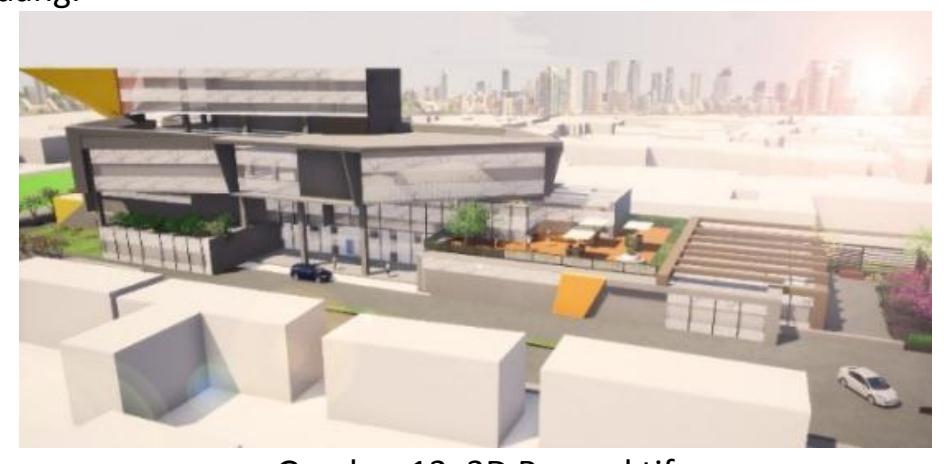

Gambar 13. 3D Perspektif

Sumber: Dokumen Pribadi

Terdapat ruang terbuka pada bagian samping bangunan, juga terdapat rooftop garden untuk penghijauan bangunan

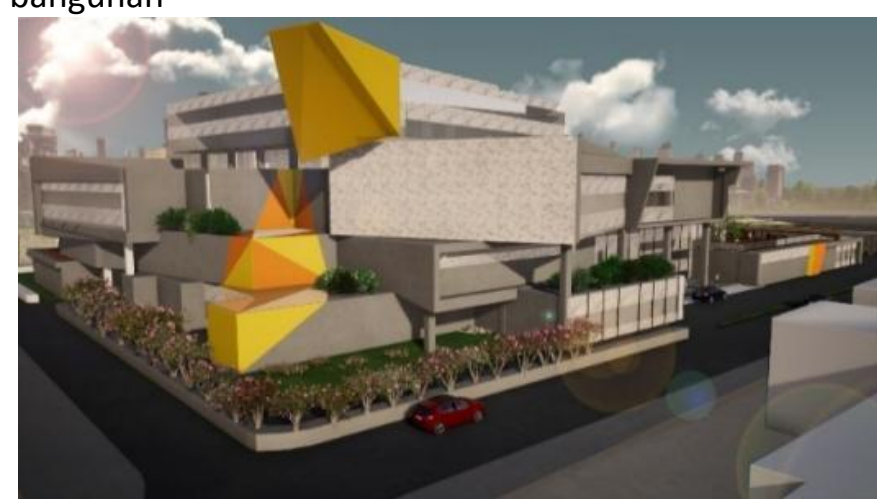

Gambar 14. 3D Perspektif

Sumber: Dokumen Pribadi 
Bangunan menggunakan fasad yang terdiri dari kaca dan beton, juga sedikit $\quad$ ACP di beberapa sisi, dan cat warna di beberapa bagian. Bagian servis bangunan adalah pada bagian samping bangunan yang menghadap jalan sekunder.

Olahraga berbasis hiburan yang ada di dalam proyek mencakup:

- Menembak

Olahraga menembak adalah olahraga kompetitif yang melibatkan tes kemahiran (akurasi dan kecepatan) dengan menggunakan berbagai jenis senjata seperti senjata api dan senapan angin.Berburu juga merupakan olahraga menembak. Olahraga menembak dikategorikan berdasarkan jenis senjata api, sasaran dan jarak di mana target dinembak.

Manfaat yang didapat dari olahraga menembak adalah :

- Membakar kalori

Rata-rata wanita akan membakar 170 kalori per jam untuk menembakkan senapan (jika berdiri).

- Meningkatkan disiplin mental

Penembak jitu berpengalaman mengatakan olahraga menembak adalah $90 \%$ mental. Tingkat konsentrasi dipertajam dan diperluas. Beberapa aktivitas pemecahan masalah yang melibatkan logika, matematika, dan pemikiran kreatif (berpikir 'di luar kotak') dibutuhkan dan digunakan untuk berhasil di setiap level olahraga menembak.

- Dapat melatih konsentrasi, ketepatan, dan kecepatan karena menembak membutuhkan konsentrasi dalam mencari sasaran tembakan untuk mencapai hasil maksimal. Ketepatan sasaran dalam menembak harus dimengerti benar. Kecepatan dibutuhkan dalam mengatur waktu yang telah ditentukan dalam setiap melakukan penembakan.

- Dapat mengontrol diri atau melatih kesabaran.

- Dapat menjadi sarana untuk melepas kepenatan dari berbagai aktivitas keseharian.

Olahraga menembak dapat terbagi dalam bentuk menembak sasaran secara langsung yang biasa digunakan dalam pelatiham militer dan juga menembak yang dimasukkan dalam permainan (combat pistol shooting). Menembak dalam permainan adalah seni bela diri modern yang berfokus pada penggunaan pistol sebagai senjata defensif untuk pertahanan diri, atau untuk penggunaan militer dan polisi. Seperti kebanyakan seni bela diri, penembakan pistol tempur dilakukan baik untuk pertahanan dan olahraga.

- Laser Neon

Laser Neon merupakan permainan yang menggunakan laser atau cahaya berwarna neon dalam permainannya. Permainannya beragam namun permainan ini biasanya dimainkan dalam keadaan gelap agar memungkinkan cahaya laser terlihat dalam gelap. Beberapa permainan yang dapat dimainkan dengan laser neon adalah: panahan yang dikombinasikan dengan dodgeball, pedang, spy laser.

- Gym

Gym merupakan adalah tempat yang menyimpan alat latihan fisik untuk keperluan latihan fisik demi kebugaran. Fasilitas yang ada terbagi kedalam beberapa jenis diantaranya: kawasan latihan utama, kawasan kardio, kelas latihan kelompok, dan juga latihan pribadi. Pusat kebugaran modern biasanya memiliki fasilitas bar kudapan, lounge anggota. Terdapat juga gym yang menawarkan fasilitas pancuran mandi. Gym terbangun adalah dengan fasilitas ruang gym yang mengkombinasikan neon dan augmented reality. Kids Arena merupakan area dimana anak- anak dapat berolahraga sambil bermain, mereka dapat memilih kegiatan yang mereka suka, dan sebagian besar kegiatan ini juga dapat membantu perkembangan motorik dan kognitif anak.

- Rooftop bar \& billiard

Billiard yang ada diatas gedung dengan fasilitas bar dan kafe untuk bersantai dan bercengkrama. 


\section{Perancangan Bangunan}

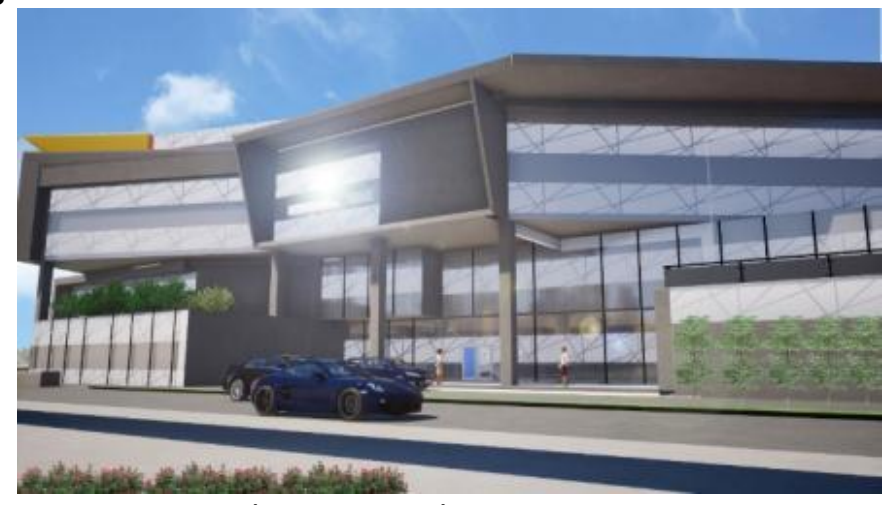

Gambar 15. 3D Eksterior Bangunan

Sumber: Dokumen Pribadi

Judul Proyek : Kemang Sportainment

Lokasi : Jalan Kemang Raya

Luas Tapak : :6078.2 $\mathrm{M}^{2}$

KDB Tapak : 50

KLB Tapak : : 2

KB : 4 lantai

Luas Bangunan : $7580 \mathrm{M}^{2}$

Fungsi

- Menjadi tempat untuk memenuhi kebutuhan olahraga

- Menjadi tempat hiburan untuk melepaskan penat

- Tempat untuk bersantai dan menghilangkan stres

- Ruang terbuka publik

\section{Interior Bangunan}

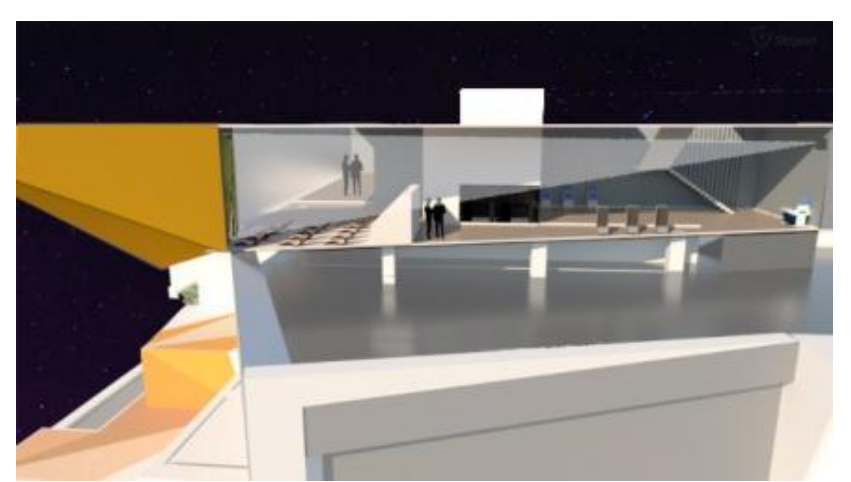

Gambar 16. Interior Lantai 4 Sumber: Dokumen Pribadi

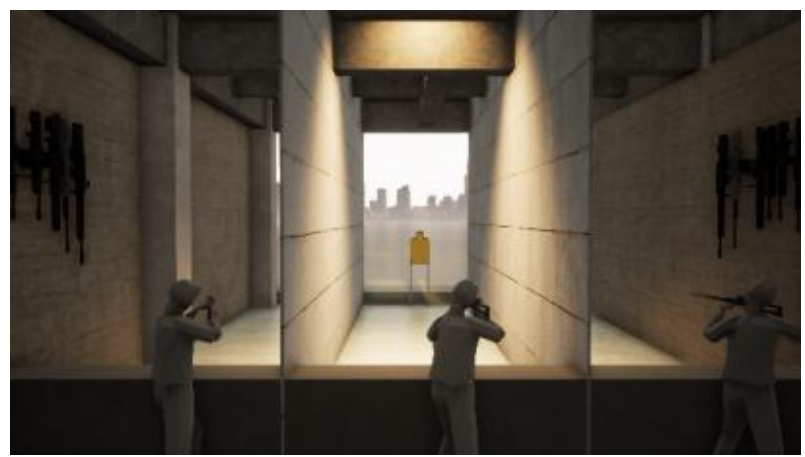

Gambar 17. Interior Latihan Menembak Sumber: Dokumen Pribadi 


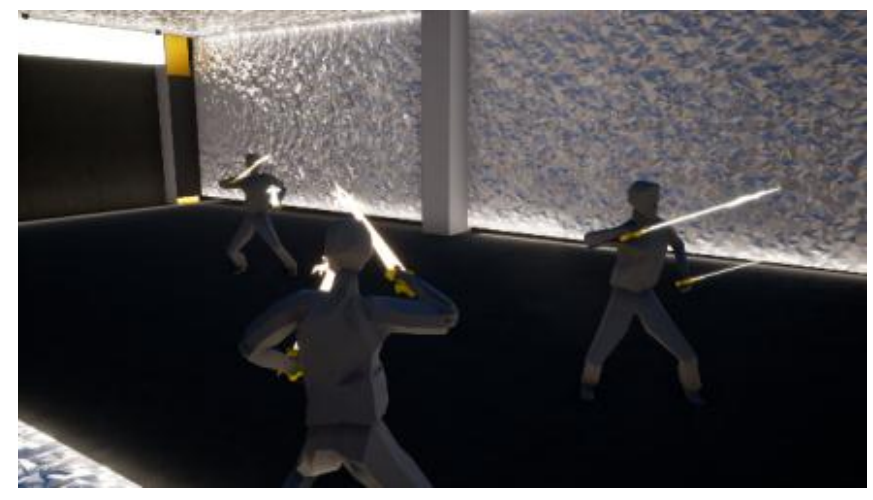

Gambar 18. Interior Ruang Laser Neon Sumber: Dokumen Pribadi

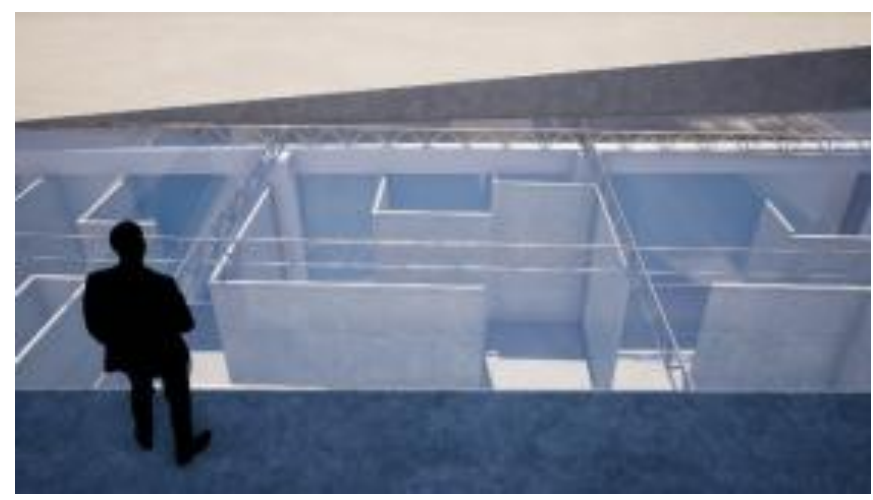

Gambar 19. Interior view dari Lantai 4 Sumber: Dokumen Pribadi
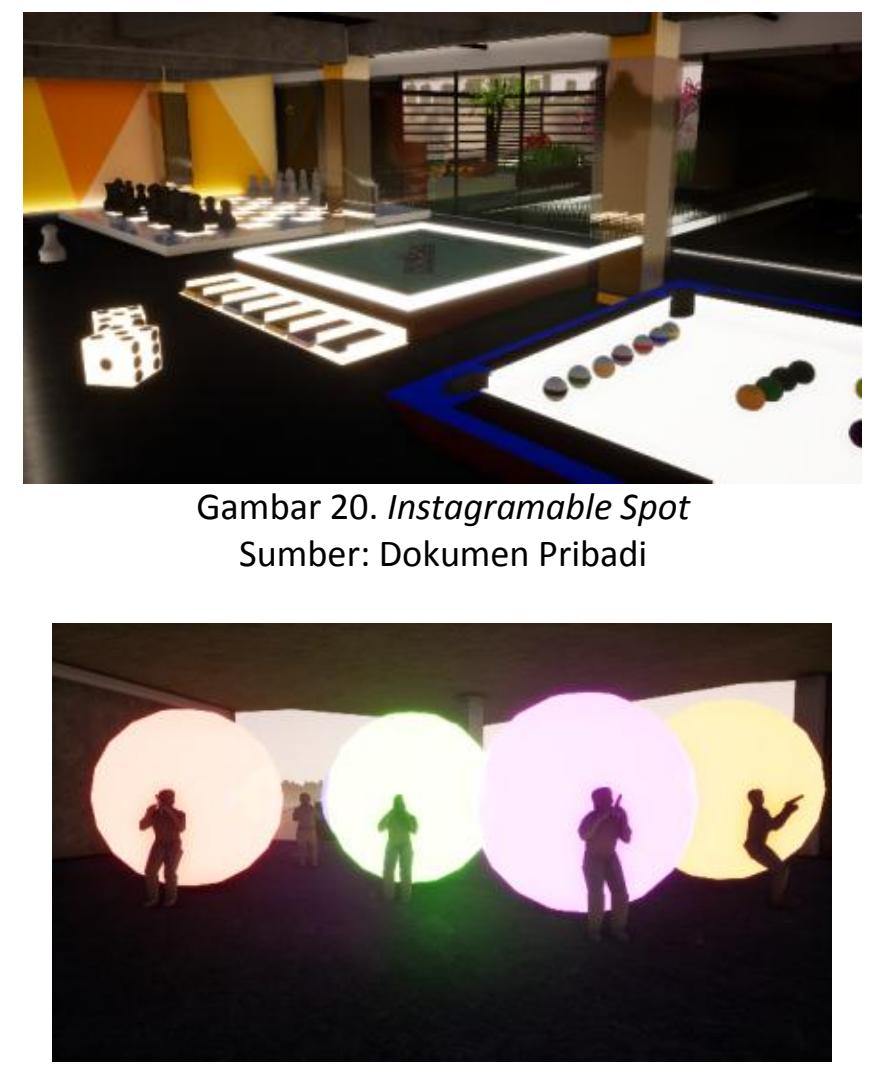

Gambar 21. Interior Arena Menembak 1 Sumber: Dokumen Pribadi 


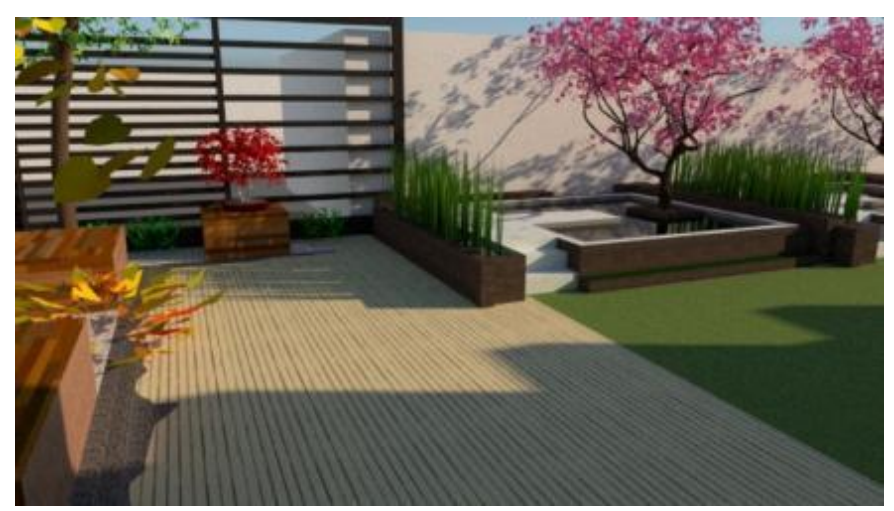

Gambar 22. Inner Courtyard

Sumber: Dokumen Pribadi

\section{KESIMPULAN DAN SARAN}

Kemang Sportainment ini merupakan sebuah wadah olahraga yang berbasis hiburan yang berisikan jenis aktifitas olahraga yang bersifat rekreasi atau dapat menjadi destinasi wisata bagi pengunjung. Kurangnya waktu dalam berolahraga dan kesibukan yang terlalu padat menyebabkan masyarakat lupa akan pentingnya berolahraga. Diharapkan Kemang Sportainment ini dapat menjadi tempat untuk melakukan kegiatan olahraga sambal melepaskan penat dari kehidupan sehari-hari.

\section{REFERENSI}

Seminar "Architourism of the Metropolis"

Pengamatan berdasarkan Peta Zonasi Tata Ruang DKI

Literatur Buku

Specht, J. (2014). Architectural Tourism . Jerman. Springer Gabler.

Bilbao Effect, Available:

Moore, R. (2017). The Bilbao Effect.

https://www.theguardian.com/artanddesign/2017/oct/01/bilbao-effect-frank-gehryguggenheim-global-craze

Data Kota Jakarta Selatan, Available:

https://id.wikipedia.org/wiki/Kota_Administrasi_Jakarta_Selatan

https://jakselkota.bps.go.id/

Wisata Olahraga, Available:

http://www.onecaribbean.org/content/files/SportsTourism.pdf

Penyebab Stres, Available:

https://lifestyle.kompas.com/read/2018/01/22/182932320/rutinitas-kerja-penyebabstres-yang-paling-umum

Remaja di Indonesia, Available:

http://www.beritasatu.com/gaya-hidup/275578-remaja-jakarta-kurang-gerak-dan-takbugar.html 